\title{
Isolation and Identification of Actin-binding Proteins in Plasmodium falciparum by Affinity Chromatography
}

\author{
Claudia Forero*, Moisés Wasserman/*/+
}

\author{
Laboratorio de Bioquímica, Instituto Nacional de Salud, Av. Eldorado Cra. 50, Bogotá, Colombia \\ *Departmento de Química, Facultad de Ciencias, Universidad Nacional de Colombia, Bogotá, Colombia
}

The invasion of the erythrocyte by Plasmodium falciparum depends on the ability of the merozoite to move through the membrane invagination. This ability is probably mediated by actin dependent motors. Using affinity columns with $G$-actin and F-actin we isolated actin binding proteins from the parasite. By immunoblotting and immunoprecipitation with specific antibodies we identified the presence of tropomyosin, myosin, $\alpha$-actinin, and two different actins in the eluate corresponding to $F$-actin binding proteins. In addition to these, a 240-260 kDa doublet, different in size from the erythrocyte spectrin, reacted with an antibody against human spectrin. All the above mentioned proteins were metabolically radiolabeled when the parasite was cultured with 35S-methionine. The presence of these proteins in $\mathrm{P}$. falciparum is indicative of a complex cytoskeleton and supports the proposed role for an actin-myosin motor during invasion.

Key words: actin - $\alpha$-actinin - malaria - myosin - spectrin - tropomyosin - Plasmodium falciparum - affinity chromatography

The invasion of erythrocytes by parasites of the genus Plasmodium is a phenomenon well-described from a morphological and ultrastructural point of view (Aikawa et al. 1978, Bannister \& Dluzewski 1990). However, the machinery and the molecular mechanisms involved in the process are practically unknown. The penetration of the erythrocyte depends on the ability of the merozoite to move through the membrane invagination. This ability is probably mediated by actin dependent motors since it is inhibited by Cytochalasin B (Miller et al. 1979, Field et al. 1993). Furthermore, in a related parasite Toxoplasma the involvement of actin fibers has been directly demonstrated (Dobrowolski \& Sibley 1996).

The cytoskeleton of Plasmodium is poorly known. Two actin genes have been characterized: one, coding for a 376-aminoacid residues protein, is expressed during the sexual and the asexual

\footnotetext{
This work was sponsored by the "Instituto Nacional de Salud" and by the "Instituto Colombiano para el Desarrollo de la Ciencia y la Tecnología-Francisco José de Caldas-Colciencias", Project: 2104-04-170-95, Bogotá, Colombia. Claudia Forero was a graduate student at the Doctoral Program of Chemistry, Faculty of Sciences, National University of Colombia.

${ }^{+}$Corresponding author. Fax: 57-1-2220975. E-mail: mwasserm@colciencias.gov.co

Received 26 July 1999

Accepted 27 January 2000
}

cycles and its sequence is highly divergent from other actin genes found in lower eukaryotes. The other one is expressed only in sexual forms (Wesseling et al. 1988a,b, 1989). With a DNAse-I inhibition assay it has been possible to show the simultaneous presence of actin fibers (F-actin) and monomers (G-actin) in the merozoite cytoplasm. Two proteins, 43 and $55 \mathrm{kDa}$ were detected with anti-actin antibodies in immunoblots. The bigger band was ubiquitinated (Field et al. 1993). The distribution of actin in the cytoplasm of the parasite has also been shown by immunofluorescence microscopy (Webb et al. 1996).

One $\beta$-tubuline and two different $\alpha$-tubuline genes have been cloned (Delves et al. 1989, Holloway et al. 1989, 1990). The microtubule organization during schizogony has been visualized by fluorescent microscopy (Read et al. 1993). Short filaments of unknown composition were shown by electron microscopy to link the plasma membrane of the merozoite with the pellicular cisternae (Bannister \& Mitchell 1995). A myosin was detected in $P$. berghe $i$ and its distribution was studied using confocal laser scanning microscopy (Suhrbier et al. 1993); recently, a myosin was also detected in P. falciparum (Pinder et al. 1998, Forero 1998). The apparent molecular weights of the former myosins are very different compared with each other and somehow strange compared with most myosins reported (Titus 1993, Mooseker \& Cheney 1995). Using F-actin affinity columns and ATPagarose chromatography Tardieux et al. (1998) identified a $70 \mathrm{kDa}$ protein (HSC70) in P. knowlesi 
merozoites, characterized as a Plasmodium heat shock protein and a doublet of $32 / 34 \mathrm{kDa}$. The HSC70/32/34 complex inhibited the polymerization of rabbit skeletal muscle actin in vitro.

In our laboratory we have studied the role of calcium during invasion and we have shown that its depletion in the medium causes an inhibition of invasion partly due to the inability of the merozoite to reorientate and penetrate the erythrocytes (Wasserman et al. 1982, 1990). It has been well established that calcium is an important mediator of assembly and disassembly of cytoskeleton (Bennet \& Weeds 1986) and of molecular motors (Barkalow \& Hartwig 1995, Wolenski 1995). The study and characterization of actin binding proteins in Plasmodium should contribute to the understanding of the force events required for the invasion. The purpose of the present work was the detection and isolation by affinity chromatography of actin binding proteins in the parasite. Some of the purified proteins were identified with antibodies against well-known and conserved $\mathrm{F}$-actin binding proteins and a myosin was immunoprecipitated from metabolic radiolabelled extracts.

\section{MATERIALS AND METHODS}

Parasite growth conditions and obtention of protein extracts - The Colombian strain FCB1 of $P$. falciparum was cultured in $\mathrm{O}(+)$ erythrocytes at 5\% hematocrit in medium RPMI 1640 (Sigma Chem. Co. St. Louis, Mo) supplemented with $10 \%$ human serum (Trager \& Jensen 1976). Cultures were synchronized with sorbitol 5\% (Lambros \& Vanderberg 1979) and parasitemias of 5-10\% schizonts were obtained after $47 \mathrm{~h}$ incubation. For 35Smethionine labeling, $100 \mathrm{ml}$ of a $7 \%$ parasitemia culture of 18-h-age rings were washed twice with HBS (Hepes $20 \mathrm{mM} \mathrm{pH} \mathrm{7.4,} \mathrm{NaCl} 160 \mathrm{mM}$ ) and resuspended in the same volume of methionine free RPMI-1640 medium. A volume of $24 \mu \mathrm{l}$ of 35Smethionine $(9.8 \mu \mathrm{Ci} / \mathrm{ml}, 1.18 \mathrm{Ci} / \mathrm{mmol}$ Amersham International plc, UK) was added and the culture was incubated for $30 \mathrm{~h}$ more. The cells were washed twice with HBS and erythrocytes were lysed with saponine $0.15 \%$ in HBS. Erythrocyte membranes were eliminated after centrifugation over a Percoll cushion (Wiser \& Lanners 1992). Free parasites were washed three times with HBS; the weight of the pellet was evaluated and the parasites were resuspended $1: 10 \mathrm{w} / \mathrm{v}$ in extraction buffer (Hepes $5 \mathrm{mM}$ pH 7.5, EDTA $0.5 \mathrm{mM}$, EGTA $0.5 \mathrm{mM}$, Nonidet P40 0.05\%, supplemented with the following mixture of protease inhibitors: PMSF $1 \mathrm{mM}$, Benzamidine $0.01 \mathrm{mM}$, Phenantroline $1 \mu \mathrm{g} / \mathrm{ml}$, Aprotinin $10 \mu \mathrm{g} / \mathrm{ml}$, Leupeptin $10 \mathrm{mg} / \mathrm{ml}$ and Pepstatin A $10 \mathrm{mg} / \mathrm{ml}$ ) and frozen at $-70^{\circ} \mathrm{C}$. Immediately before chromatography one volume of the extraction buffer with protease inhibitors was added to the parasite suspension, and it was homogenized with a teflon Potter-Elvehjem homogenizer with ten strokes at maximum speed.The suspension was centrifuged at $10.000 \mathrm{xg}$ during $20 \mathrm{~min}$; the supernatant was adjusted to a concentration of $50 \mathrm{mM}$ Hepes pH 7.5, DTT $2 \mathrm{mM}$ and centrifuged again at $100.000 \mathrm{xg}$ during $1 \mathrm{~h}$ to remove ribosome, membranes and residual polymeryzed cytoskeleton proteins. The clear supernatant was loaded to the affinity columns for chromatography. The same process was followed with uninfected erythrocytes as a control to verify the parasitic source of the radiolabeled proteins.

Affinity chromatography - F-actin columns Bovine muscle actin (Sigma) was resuspended in a low ionic strength buffer -buffer G- (Hepes $5 \mathrm{mM}$ $\mathrm{pH} 7.5, \mathrm{CaCl}_{2} 0.2 \mathrm{mM}$ and ATP $0.2 \mathrm{mM}$ ) and was polymerized by adding Hepes to reach $50 \mathrm{mM}, \mathrm{KCl}$ to $0.1 \mathrm{M}$ and $\mathrm{MgCl}_{2}$ to $5 \mathrm{mM}$ (buffer F). The mixture was incubated at $20^{\circ} \mathrm{C}$ for $1 \mathrm{~h}$ and Phalloidin was added to the mixture to reach an equimolar concentration with the actin. Polymerization was checked out by electrophoresis in $5 \%$ polyacrilamide gels under denaturing and non-denaturing conditions. The F-actin columns were prepared as described (Miller \& Alberts 1989, Miller et al. 1991) with slight modifications. All procedures were performed at $4^{\circ} \mathrm{C}$. Two $\mathrm{ml}$ of Affigel-10 (BioRad, Richmond, CA) and $2 \mathrm{ml}$ of SepharoseCl6B (Pharmacia Biotech, Piscataway, NJ) were carefully mixed in a 1-cm-diam and 10-cm-long glass column. The mixture was washed three times with deionized water and twice with buffer F containing $10 \mu \mathrm{g} / \mathrm{ml}$ Phalloidin. The buffer was drained out and $2 \mathrm{ml}$ of previously polymerized actin were added to a protein concentration of 2.5 $\mathrm{mg} / \mathrm{ml}$. The mixture was left overnight with very gentle agitation on a rotatory mixer (Taiyo RT50). After the former step, the column was left in a vertical position for $1 \mathrm{~h}$, the supernatant was carefully drained out and the gel was washed with 3 vol of buffer $\mathrm{F}$ with a flow rate of $3 \mathrm{ml} / \mathrm{h}$. The column was stored with buffer F supplemented with $10 \mu \mathrm{g} /$ $\mathrm{ml}$ Phalloidin and $0.02 \% \mathrm{NaN}_{3}$.

The F-actin columns were checked out for their binding specificity by doing a chromatography of a mixture of commercial pure bovine myosin (Sigma) and BSA (Bovine Serum Albumin). The mixture, $2 \mathrm{ml}$ containing $1 \mathrm{mg} / \mathrm{ml}$ of each protein in sample buffer A (Hepes $50 \mathrm{mM} \mathrm{pH} 7.5$, DTT 2 $\mathrm{mM}$, EGTA $0.5 \mathrm{mM}$, EDTA $0.5 \mathrm{mM}, \mathrm{KCl} 50 \mathrm{mM}$, Nonidet P40 $0.05 \%$, glicerol $10 \%$ and the above described mixture of protease inhibitors), was applied at a flow rate of column vol/h. Unbound proteins were eluted with the same buffer. After extensive washing, the bound proteins were eluted 
in two steps. The first with $5 \mathrm{ml}$ of buffer A plus ATP $1 \mathrm{mM}$ and $\mathrm{MgCl}_{2} 3 \mathrm{mM}$ and the second with $5 \mathrm{ml}$ of the same solution added with $\mathrm{KCl} 1 \mathrm{M}$. Fractions were analyzed by SDS-PAGE. The column was used five times with identical results.

$G$-actin columns - The resin and the column were prepared as formerly described. The affigel10 was preincubated 90 min with buffer $\mathrm{G}$ and washed twice with the same buffer. Two $\mathrm{ml}$ of bovine $\mathrm{G}$-actin $(3 \mathrm{mg} / \mathrm{ml})$ in buffer $\mathrm{G}$ were added and mixed as described. Unbound protein was drained out and the mixture was left during $3 \mathrm{~h}$ in $2 \mathrm{ml}$ of buffer $\mathrm{G}$ containing $50 \mathrm{mM}$ ethanolamine $\mathrm{pH}$ 7.8. The column was washed again and used only once during the week following its preparation.

BSA column - The control column was prepared as described for the F-actin column, (but this time no Phalloidin was added). Four $\mathrm{ml}$ of a $4 \mathrm{mg} / \mathrm{ml}$ BSA solution in buffer F were used.

Affinity chromatography - Chromatography was carried out simultaneously on the three columns using a multichannel peristaltic pump (WIZISCO). After stabilizing the columns with buffer $\mathrm{A}, 1 \mathrm{ml}$ of the extract was loaded at a flow rate of 0.5 column-vol $/ \mathrm{h}$ (the extracts contained $10^{8} \mathrm{DPM} /$ $\mathrm{ml}$ or $4 \mathrm{mg}$ protein/ml). Four $1 \mathrm{ml}$ fractions containing the unbound proteins were collected. The columns were washed with four column-volumes of buffer A, and the bound proteins were eluted in two steps as formerly described. Fractions were analyzed on $8 \%$ SDS polyacrilamide gels that were silver stained (Oakley et al. 1980), dried, and exposed to Hyperpaper-35S (Amersham) for autoradiography.

Electrophoresis, immunoblot and slot blot - The samples were electrophoresed as described (Laemmli 1970) and transferred to Immobilon $P$ (Millipore, Bedford,MA) at $0.8 \mathrm{~mA} / \mathrm{cm}^{2}$ (Towbin et al. 1979). Membranes were blocked by overnight incubation with a solution containing Tris$\mathrm{HCl} 20 \mathrm{mM} \mathrm{pH}$ 7.5, NaCl $150 \mathrm{mM}$, Tween20 0.1\% and fat-free dry milk 5\%. The following twelve antibodies were used to test the isolated proteins: a polyclonal against bovine muscle-myosin (Sigma M-7648); a monoclonal anti-pan-myosin (Amersham RPN-1169); a monoclonal against human myosins I and II produced in Dr Simon Hughes' laboratory at MRC (Medical Research Council), Randall Institute, King's College London; a polyclonal against a multiantigenic 15 residue-oligopeptide specific for $P$. falciparum myosin produced by Dr Jeni Pinder MRC London; a polyclonal anti-chicken actin (bm1082, Biomakor bm, Science and Medicine, Israel); a polyclonal against chicken $\alpha$-actinin (BioMakor-bm1087); a monoclonal against chicken filamin (BioMakorbm 1076); a monoclonal against chicken vinculin
(BioMakor-bm 6501); a polyclonal against tropomyosin (BioMakor-bm1090); a polyclonal against human spectrin produced in our laboratory; a polyclonal against human spectrin produced by Dr Jeni Pinder at MRC, and a monoclonal against gelsolin (Sigma G-4896).

All the primary and secondary antibodies were carefully titrated and diluted in blocking buffer to avoid inespecificity. The membranes were incubated with primary antibodies at room temperature with gentle shaking during $1 \mathrm{~h}$. They were washed four times with a solution containing Tris$\mathrm{HCl} 20 \mathrm{mM} \mathrm{pH} 7.5, \mathrm{NaCl} 150 \mathrm{mM}$ and Tween 20 $0.1 \%$. As secondary antibodies we used biotinylated anti-rabbit-IgG (BRL Life Technologies Inc, Gaithersburg, MD), biotinylated antimouse-IgG (Amersham), biotinylated anti-goatIgG (Sigma), peroxidase conjugated anti-mouse IgG (Dako, Denmark), and a streptavidine conjugated with alkaline-phosphatase (Amersham). The final conjugate was incubated at the previously established dilution for $1 \mathrm{~h}$ and washed as described. For signal development, 5bromo-4chloro3indoyl-phosphate (BCIP) and nitroblue tetrazolium were used with alkaline phosphatase and the ECL Western Blottyng System (Amersham) with peroxidase.

The slot blot was done as follows: samples containing 1 and $2 \mu \mathrm{g}$ of rabbit muscle myosin or of column protein eluates were filtered on a nitrocellulose membrane using a Bio-Dot SF (BioRad) equipment. The membranes were dried between two Whatman 3MM filters and the signal was developped with HRP-conjugated secondary antibodies using the ECL Western Blotting System (Amersham).

Immunoprecipitation - The immunoprecipitation was carried out both with the radiolabelled crude extracts and with the fractions eluted from the affinity chromathography. We used the Firestone and Winguth (1990) method as follows: to avoid inespecific reactions, the antigen-antibody reaction took place in the presence of BSA, in HENN 250 buffer ( $25 \mathrm{mM}$ Hepes KOH pH 7.5/5 mM EDTA pH 7.5/250 mm NaCl/1\% Nonidet P40). We used $20 \mu \mathrm{l}$ of the monoclonal antibody (anti-Pan myosin Amersham RPN-1169) at a 1:10 dilution and $300 \mu \mathrm{l}$ of the radiolabelled fractions. The positive control used was bovine muscle myosin (Sigma M-6643). To demonstrate the specificity of the immunoprecipitation assay we performed a control using the same samples eluted from the F actin column but without the addition of the primary anti-myosin antibody. The samples were left overnight in low agitation at $4^{\circ} \mathrm{C}$, and after adding $20 \mu \mathrm{l}$ of the secondary antibody (rabbit anti-mouse Igs) at 1:50 dilution, they were incubated for $1 \mathrm{~h}$ at 
$20^{\circ} \mathrm{C}$. Afterwards, we added $20 \mu \mathrm{l}$ of Sepharose 4B Protein G (Sigma P 3296) to each tube and we incubated them with agitation for $5 \mathrm{~min}$. Then the samples were layered over a $1 \mathrm{M}$ Sucrose cushion in HENN 250 buffer and were centrifuged for 3 $\min$ at $10.000 \mathrm{xg}$ and $20^{\circ} \mathrm{C}$. The unadsorbed proteins were eliminated carefully from the top of the tube and the walls of the tube in contact with the sample were carefully washed with $2 \mathrm{M}$ urea in 500 HENN buffer $(500 \mathrm{mM} \mathrm{NaCl}$ and other components as in $250 \mathrm{HENN}$ ) for $2 \mathrm{~min}$. Finally, the urea and the sucrose were discarded and the pellet was washed twice with 250 HENN buffer and once with the same buffer without detergent. The pellet was resuspended in Laemmli buffer for SDSPAGE. The gel was electrotransfered to a PVDF (Millipore) membrane and was exposed to Hyperpaper-35S (Amersham) at $-70^{\circ} \mathrm{C}$.

\section{RESULTS}

Affinity chromatography - We tried to construct affinity columns for filamentous actin (F-actin), stabilizing the fibers with chemical crosslinkers (Miller et al. 1991) or with Phalloidin (Miller \& Alberts 1989). When we used the chemical crosslinker dimethylsuberimidate we found it was not efficient to construct the columns. At the reported concentration of $10 \mu \mathrm{g} / \mathrm{ml}$, Phalloidin was not enough to maintain long fibers. We tested higher concentrations, and we found that when they were equivalent to one or two times the molar concentration of actin, the polymerization and the stability of the filament were efficient and the binding of the fibers to the gel improved. Six F-actin columns were used through the present work and the binding of actin to the support varied between 85.2 to $96 \%$. The specificity of the F-actin columns was verified doing a chromatography of a sample prepared by mixing BSA and myosin (from bovine skeletal muscle). Fig. 1 shows that BSA did not bind to the column and eluted with the void volume and the initial washing. The myosin bound strongly to the F-actin. It eluted only with a solution that contained ATP, $\mathrm{Mg}^{2+}$ and $1 \mathrm{M} \mathrm{KCl}$.

The G-actin columns were prepared similarly, but in a buffer that prevented polymerization. Around $54 \%$ of the G-actin was incorporated to the gel support. The BSA bound to the gel in the control columns with an efficiency of $75 \%$.

Similar $1 \mathrm{ml}$ samples containing $10^{8} \mathrm{DPM}$ of a 35S-methionine-labeled parasite-protein extract were loaded on F-actin, G-actin and BSA columns. The chromatography was performed as described in Materials and Methods, under identical conditions in the three columns. Radioactivity was quantified and the eluted fractions were analyzed by SDS-PAGE and autoradiography. A $2.9 \%$ of the

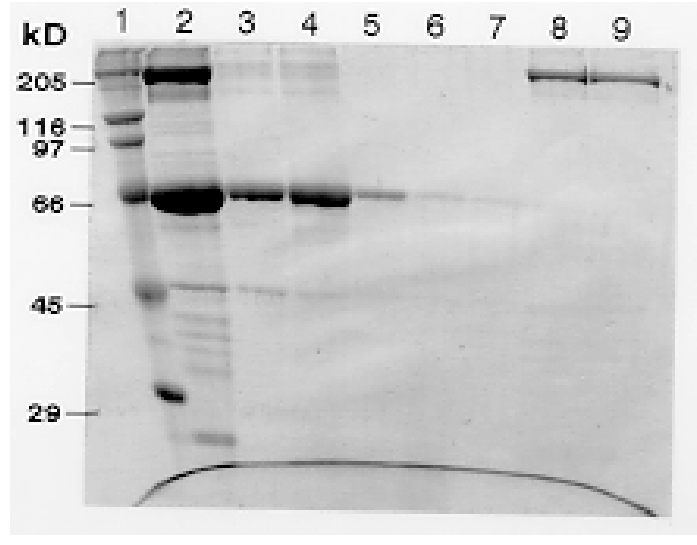

Fig. 1: specificity of the F-actin column. A mixture of myosin and BSA was subjected to chromatography as described in Materials and Methods. A Coomassie stained SDS-PAGE of the different fractions is shown. The samples were analyzed in the electrophoresis as follows: lane 1 - Molecular weight markers; lane 2 - The mixture of bovine myosin and BSA; lanes 3 and 4 - Fractions eluted after loading the mixture, (mostly unbound BSA ); lanes 5 and 6 - Washing fractions; lane 7- Fraction eluted with the low ionic strength buffer ( $1 \mathrm{mM} \mathrm{ATP,} 3$ $\mathrm{mM} \mathrm{MgCl} 2$ ); lanes 8 and 9 - Myosin eluted with high ionic strength buffer ( $1 \mathrm{mM} \mathrm{ATP,} 3 \mathrm{mM} \mathrm{Mg} \mathrm{Cl} 2$ and $1 \mathrm{M} \mathrm{KCl}$ ).

radioactivity bound to the F-actin column. Ten proteins were eluted from the F-actin column with the addition of ATP and $\mathrm{Mg}^{2+}$, and six more when the concentration of $\mathrm{KCl}$ was raised to $1 \mathrm{M}$ (Fig. $2 \mathrm{~A})$. Only $0.9 \%$ of the radioactivity bound to the G-actin column. Two proteins were eluted with ATP and $\mathrm{Mg}^{2+}$, and two more with the addition of $\mathrm{KCl}$ to $1 \mathrm{M}$ (Fig. 2B). No protein bound to the BSA control column (Fig. 2C).

Identification of $F$-actin binding proteins - The 16 proteins that eluted from the F-actin columns with ATP, $\mathrm{Mg}^{++}$and $1 \mathrm{M} \mathrm{KCl}$ were separated by SDS-PAGE and transferred to PVDF-cellulose membranes. Several different antibodies against known and conserved actin binding proteins were used to assay strips of the membrane containing the electrophoresed proteins. One polyclonal antibody against tropomyosin (chicken gizzard) recognized three proteins. One sized $45 \mathrm{kDa}$ produced a very strong signal, while the other two of 33 and $34 \mathrm{kDa}$ produced mild signals (Fig. 3A). A polyclonal antibody against chicken actin recognized two defined proteins of 43 and $55 \mathrm{kDa}$ (Fig. 3B). Those proteins probably correspond to the reported normal and ubiquitinated forms of the parasite actin (Field el al. 1993). An anti $\alpha$-actinin (chicken gizzard) polyclonal antibody detected two bands of 100 and $56 \mathrm{kDa}$ (Fig. 3C).

Two proteins were recognized with two different antibodies against human erythrocyte spectrin (Fig. 3D). They seem to be of parasitic origin, since 


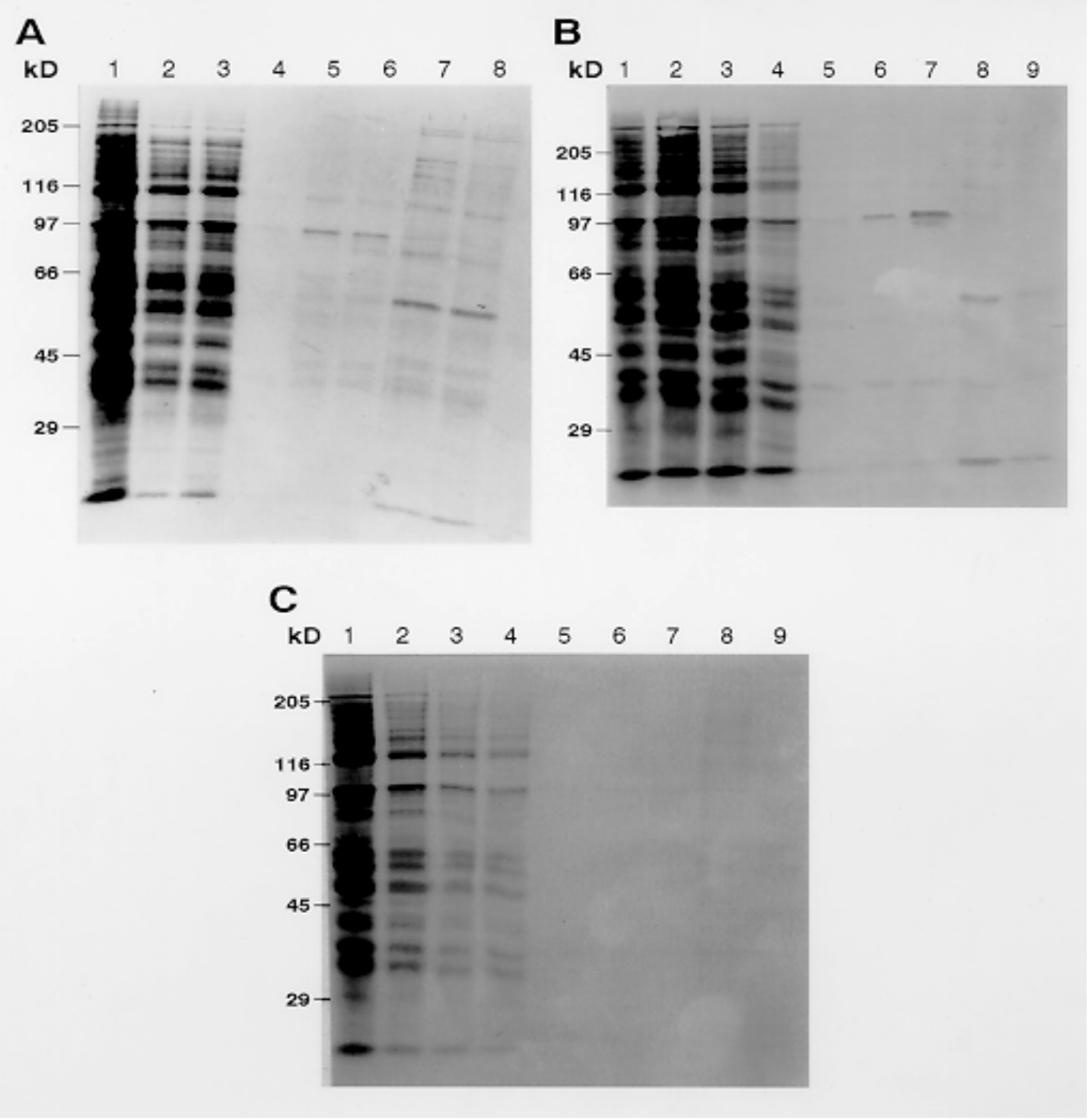

Fig. 2: isolation of G-actin and F-actin binding proteins of Plasmodium falciparum. A 35S-methionine radiolabeled extract of $P$. falciparum proteins was submitted to affinity chromatography in F-actin (A), G-actin (B) and BSA (C) columns. Autoradiographies of the SDS-PAGE gels of the different fractions are shown here. In (A), lane 1 corresponds to the parasite extract before chromatography, lanes 2 and 3 to unbound proteins, lane 4 to the final wash before elutions, lanes 5 and 6 to proteins eluted with low ionic strength buffer ( $1 \mathrm{mM}$ ATP, $3 \mathrm{mM} \mathrm{MgCl} 2$ ), and lanes 7 and 8 to proteins eluted with high ionic strength buffer ( $1 \mathrm{mM}$ ATP, $3 \mathrm{mM} \mathrm{Mg} \mathrm{Cl}$ and $1 \mathrm{M} \mathrm{KCl}$ ). In (B) and (C), lanes 1-3 are as in (A), lanes 4 and 5 correspond to washing before elution, lanes 6 and 7 to proteins eluted with low ionic strength buffer and lanes 8 and 9 to proteins eluted with high ionic strength buffer.

they were labelled with 35S-methionine (Fig. 1A, lane 7). They show a degradation pattern different from that of the human spectrin (not shown), and they apparently have a molecular weight slightly higher than that of human spectrins.

Using two different antibodies against myosin, a polyclonal prepared against bovine skeletal muscle myosin and a monoclonal against human myosins I and II, we identified two bands of 120 and $72 \mathrm{kDa}$ (Fig. 3E, lanes 4, 5). An antibody against a $P$. falciparum myosin peptide (kindly provided by Dr Walter Gratzer from MRC London) recognized myosin in a slot-blot (Fig. 3F) of the mixture eluted from the F-actin column, but not a bovine muscle myosin. Moreover, a myosin was immunoprecipitated from a crude radiolabeled extract with the anti-pan-myosin antibody, the molecular weight of the protein being $120 \mathrm{kDa}$ (Fig. 


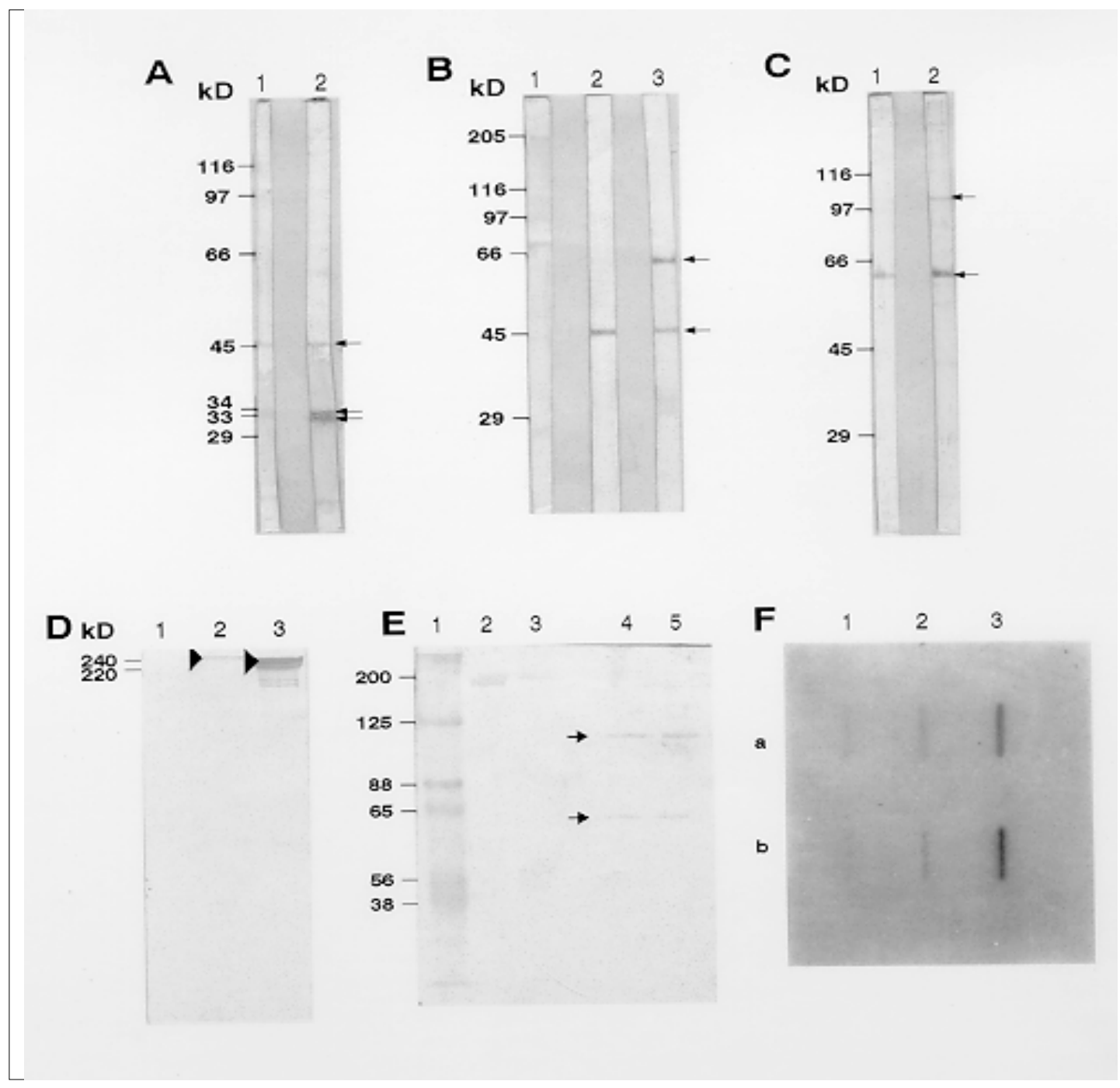

Fig. 3: identification of F-actin binding proteins by immunoblot. The mixture of F-actin binding proteins obtained from the affinity chromatography was electrophoresed on SDS-PAGE gels (8\% acrylamide) and transferred to PVDF-cellulose filters. The following proteins were detected (arrows) using specific antibodies as was described: (A) policlonal anti-tropomyosin, lane 1 fraction eluted with low ionic strength and lane 2 with high ionic strength; (B) policlonal anti-actin, lane 1 erythrocyte membranes and lane 2 and 3 low and high ionic strength eluates, respectively; (C) policlonal anti $\alpha$-actinin, as in A; (D) policlonal anti spectrin, lane 1 erythrocyte membranes, lines 2 and 3 low and high ionic strength eluates, respectively; (E) policlonal anti myosin, lane 1 molecular weight markers, and lanes 2 and 3 low and high ionic strength eluates, respectively; (F) slot blot recognized by a policlonal anti Plasmodium falciparum myosin peptide. Column 1 is rabbit muscle myosin. Columns 2 and 3 are low and high ionic strength eluates, respectively. In A, $1 \mu \mathrm{g}$ was loaded and in B, $2 \mu \mathrm{g}$ of total protein were loaded.

4), which coincides with the band identified by immuno-blot. Negative results were obtained with antibodies against vinculin, gelsolin and filamin.

\section{DISCUSSION}

We isolated several proteins of $P$. falciparum that bind specifically to G-actin and to F-actin. The parasite proteins were metabolically radiolabeled and some of them were identified using antibodies raised against the conserved homologous proteins of other organisms. These proteins were not detectable in the erythrocyte extract (data not shown), demonstrating their parasite origin.

Four proteins bound to the G-actin column (Fig. $2 \mathrm{~B})$. Two of them with molecular weights of about 100 and $97 \mathrm{kDa}$ eluted with ATP and $\mathrm{Mg}^{2+}$, and were present in the same fraction of the F-actin column. The other two eluted when the salt concentration was raised to $1 \mathrm{M} \mathrm{KCl}$ : one, $55 \mathrm{kDa}$, was also isolated in the F-actin column and has the same 


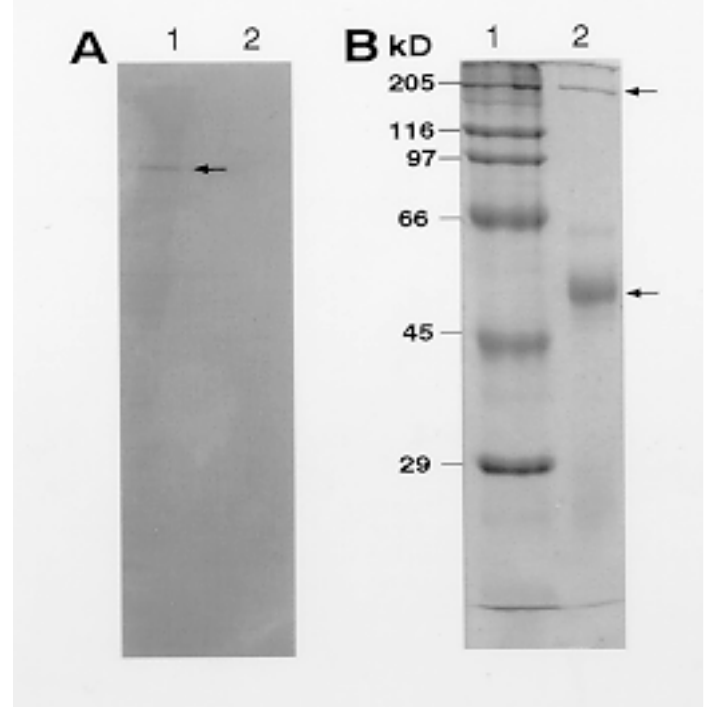

Fig. 4: myosin immunoprecipitation. (A) Autoradiography of the protein that immunoprecipitated with the anti-pan myosin antibody (lane 1), and control without primary antibody (lane 2); (B) SDS-PAGE of the bovine myosin immunoprecipitation control (lane 2), molecular weight markers (lane 1) and the antibody used for immunoprecipation (lane 3).

molecular weight of the reported ubiquitinated actin (Field et al. 1993). The other one, a protein of $13 \mathrm{kDa}$, could be a profilin, although we were not able to confirm its identity. Profilin has been found in most eukaryotic cells playing an important role in the regulation of the polymerization kinetics of actin fibers (Goldschmidt-Clermont et al. 1990, Machesky \& Pollard 1993).

Several proteins were isolated from the F-actin columns. Most eluted when besides the $1 \mathrm{mM}$ ATP and $3 \mathrm{mM} \mathrm{Mg}^{2+}$, the salt concentration was $1 \mathrm{M}$ $(\mathrm{KCl})$. A similar result was reported when F-actin binding proteins of chicken gizzard were purified (Miller \& Alberts 1989). It is interesting to point out a high molecular weight doublet (approx. 260$240 \mathrm{KDa}$ ), that migrates in a slightly different way from the human host spectrin, and was recognized by anti-spectrin antibodies. The proteins are undoubtedly from parasite origin since they were metabolically radiolabeled. In several unicellular organisms, non-erythroid spectrins have been described. In Toxoplasma gondii two proteins 240$245 \mathrm{kDa}$, immunogenically related to human spectrin, were localized by immunofluorescence on the apical end of the parasite (tachyzoite) (Ghazali et al 1995). In trophozoites of Gregaria blaberae, a spectrin-like protein was detected by immunobloting (Ghazali et al 1989). In Acanthoameba castellanii, a $260 \mathrm{kDa}$ protein that reacted with anti-spectrin but not with anti-filamin antibodies was reported (Pollard 1984). This last finding coincides with the one presented here, since in our case the doublet reacted with anti-spectrin but not with anti-filamin antibodies. This fact suggests that although the parasite protein is similar enough to be recognized by antibodies against human-spectrin, it is significantly different from the chicken filamin used to raise the antibodies. The functions of spectrin in non-erythrocitic cytoskeletons are probably dependent on its broad range of interaction with other proteins (Cianci et al. 1996, Viel \& Branton 1996). Apparently, filamin forms more flexible networks than spectrin because of the strong interaction of the latter with ankyrin (Way et al. 1991). The role of spectrin in an organism as complex, and with rapid morphological changes as Plasmodium, is intriguing.

We detected a $120 \mathrm{kDa}$ protein that was recognized in immunoblots by two different antibodies against myosin, and also in two non-denaturating assays; in slot blot, by an anti-peptide antibody specific for $P$. falciparum myosin, and in an immunoprecipitation with an anti-pan-myosin antibody. Weeb et al. (1996) have shown that a polyclonal antibody against myosin recognized the apical end of $P$. falciparum merozoites and three proteins of 110,85 and $78 \mathrm{kDa}$ in immunoblots.

A polyclonal anti $\alpha$-actinin recognized two proteins $(100$ and $55 \mathrm{kDa})$ in the fractions purified with the F-actin column. In other organisms $\alpha$ actinin was reported to crosslink actin fibers (Critchley 1993). An anti-tropomyosin antibody detected three proteins, one of $45 \mathrm{kDa}$ and a doublet of 33-34 kDa. Tropomyosin is very well known for its regulation of the motility of myosin-actin molecular motors (Pittenger et al. 1994, Wolenski 1995).

What is known of the actin and actin genes in Plasmodium leads to the obvious assumption of the existence of actin binding proteins in the parasite. We present here direct evidence of the existence in Plasmodium of a myosin, and also of a spectrin-like protein, an $\alpha$-actinin, and a tropomyosin. This preliminary finding opens the way to further studies on the proteins and their possible role in the biological process of the invasion. The recent finding that cytochalasin B and E apparently do not cause a significant depolymerization of actin fibers in the parasite (Webb et al. 1996) may imply that different proteins are acting by capping and crosslinking, thus stabilizing the actin filament network. Force events and cytoskeletal rearrangement seem to be crucial during the invasion of Plasmodium, thereby stressing the importance of a better knowledge of the proteins involved in those processes and of their interactions. 


\section{REFERENCES}

Aikawa M, Miller LH, Johnson J, Rabbege J 1978. Erythrocyte entry by malarial parasites. J Cell Biol 77: 72-81.

Bannister LH, Dluzewski AR 1990. The ultrastructure of red cell invasion in malaria infections: a review. Blood Cells 16: 257-292.

Bannister LH, Mitchell GH 1995. The role of the cytoskeleton in Plasmodium falciparum merozoite biology: an electron-microscopic view. Ann Trop Med Parasitol 89: 105-111.

Barkalow K, Hartwig JH 1995. The role of actin filament barbed-end exposure in cytoskeletal dynamics and cell motility. Biochem Soc Trans 23: 451-456.

Bennett J, Weeds A 1986. Calcium and the cytoskeleton. Br Med Bull 42: 385-390.

Cianci CD, Kim JC, McLaughlin J, Stabach PC, Lombardo CR, Morrow JS 1996. Spectrin isoform diversisty and assembly in non-erythroid cells. Cell Mol Biol Lett 1: 78-88.

Critchley DR 1993. $\alpha$-actinins. In T Kreis \& R Vale (eds), Guidebook to the Cytoskeletal and Motor Proteins, Oxford University Press, New York, p. 22-23.

Delves CJ, Ridley RG, Goman M, Holloway SP, Hyde JE, Scaife JG 1989. Cloning of ß-tubulin gene from Plasmodium falciparum. Mol Microbiol 3: 1511-1519.

Dobrowolski JM, Sibley LD 1996. Toxoplasma invasion of mammalian cells is powered by the actin cytoskeleton of the parasite. Cell 84: 933-939.

Field SJ, Pinder JC, Clough B, Dluzewski AR, Wilson RJM, Gratzer WB 1993. Actin in the merozoite of the malaria parasite, Plasmodium falciparum. Cell Motility Cytoskel 25: 43-48.

Firestone GL. Winguth SD 1990. Immunoprecipitation of proteins. In MP Deucher, Methods in Enzimology, Guide to Protein Purification. Academic Press, San Diego, Vol 182, p. 688-700.

Forero C 1998. Proteinas de Unión a Actina en Plasmodium falciparum, $\mathrm{PhD}$ Thesis, Universidad Nacional de Colombia, Santafé de Bogotá, 207 pp.

Ghazali M, Philippe M, Deguercy A, Gounon P, Gallo JM, Schrével J 1989. Actin and spectrin-like $(\mathrm{Mr}=260-240000)$ proteins in gregarines. Biol Cell 67: 173-184.

Ghazali M, Rodier MH, Elmoudni B, Babin P, Fernandez B, Jacquemin JL 1995. Detection and immunolocalization of human erythrocyte spectrin immunoanalogues in Toxoplasma gondii (protozoan, parasite). J Euk Microbiol 42: 427-433.

Goldschmidt-Clermont PJ, Machesky LM, Baldassare JJ, Pollard TD 1990. The actin-binding protein profilin binds to PIP2 and inhibits its hydrolysis by phospholipase C. Science 247: 1575-1577.

Holloway SP, Gerousis M, Delves CJ, Sims PF, Scaife JG, Hyde JE 1990. The tubulin genes of the human malaria parasite Plasmodium falciparum, their chromosomal location and sequence analysis of the $\alpha$ tubulin-II gene. Mol Biochem Parasitol 43: 257-270.

Holloway SP, Sims PF, Delves CJ, Scaife JG, Hyde JE 1989. Isolation of $\alpha$-tubulin genes from the human malaria parasite, Plasmodium falciparum: sequence analysis of $\alpha$-tubulin. Mol Microbiol 3: 1501-1510.
Laemmli UK 1970. Cleavage of structural proteins during the assembly of the head of bacteriophage T4. Nature 227: 680-685.

Lambros C, Vanderberg J 1979. Synchronization of the Plasmodium falciparum erythrocytic stages in culture. J Parasitol 65: 418-420.

Machesky LM, Pollard TD 1993. Profilin as a potential mediator of membrane-cytoskeleton communication. Trends in Cell Biol 3: 381-385.

Miller KG, Alberts BM 1989. F-actin affinity chromatography: Technique for isolating previously unidentified actin-binding proteins. Proc Natl Acad Sci USA 86: 4808-4812.

Miller KG, Field CM, Alberts BM, Kellog DR 1991. Use of actin filament and microtubule affinity chromatography to identify proteins that bind to the cytoskeleton. In R Vallee, Methods in Enzymology, Academic Press, San Diego, Vol 196, p. 303-318.

Miller LH, Aikawa M, Johnson JG, Shiroishi T 1979. Interaction between Cytochalasin B treated malarial parasites and the erythrocyte. J Exp Med 149: 172184.

Mooseker MS, Cheney RE 1995. Unconventional myosins. Ann Rev Cell Dev Biol 11: 633-675.

Oakley BR, Kirsch DR, Morris NR 1980. A simplified ultrasensitive silver stain for detecting proteins in polyacrylamide gels. Anal Biochem 105: 361-363.

Pinder JC, Fowler RE, Dluzewski AR, Bannister LH, Lavin FM, Mitchell GH, Wilson RJM, Gratzer WB 1998. Actomyosin motor in the meroziote of the malaria parasite, Plasmodium falciparum: implications for red cell invasion. J Cell Sci 111: 1831-1839.

Pittenger MF, Kazzaz JA, Helfman DM 1994. Functional properties of non-muscle tropomyosin isoforms. Current Opinion Cell Biol 6: 96-104.

Pollard TD 1984. Purification of a high molecular weight actin filament gelation protein from Acanthamoeba that shares antigenic determinants with vertebrate spectrins. J Cell Biol 99: 1970-1980.

Read M, Sherwin T, Holloway SP, Gull K, Hyde JE 1993. Microtubular organization visualized by immunofluorescence microscopy during erythrocytic schizogony in Plasmodium falciparum and investigation of post-translational modifications of parasite tubulin. Parasitology 106: 223-232.

Suhrbier A, Sinden RE, Couchman A, Fleck SL, Kumar S, McMillan D 1993. Immunological detection of cytoskeletal proteins in the exoerythrocytic stages of malaria by fluorescence and confocal laser scanning microscopy. J Euk Microbiol 40: 18-23.

Tardieux I, Baines I, Mossakowska M, Ward G 1998. Acting-binding proteins of invasive malaria parasites and the regulation of actin polimerization by a complex of 32/34-kDa proteins associated with heat shock protein 70kDa. Mol Biochem Parasitol 93: 295-308.

Titus MA 1993. Myosins. Current Opinion Cell Biol 5: 77-81.

Towbin H, Staehelin T, Gordon J 1979. Electrophoretic transfer of proteins from polyacrylamide gels to nitrocellulose sheets: procedure and some applications. Proc Natl Acad Sci USA 76: 673-675. 
Trager W, Jensen J 1976. Human malaria parasite in continuous culture. Science 193: 673-675.

Tiel A, Branton D 1996. Spectrin: On the path from structure to function. Current Opinion Cell Biol 8: 49-55.

Wasserman M, Alarcon C, Mendoza PM 1982. Effects of $\mathrm{Ca}^{2+}$ on the asexual cell cycle of Plasmodium falciparum. Am J Trop Med Hyg 31: 711-717.

Wasserman M, Vernot JP, Mendoza PM 1990. Role of calcium and erythrocyte cytoskeleton phosphorylation in the invasion of Plasmodium falciparum. Parasitol Res 76: 681-688.

Way M, Pope B, Weeds A 1991. Molecular biology of actin binding proteins: evidence for a common structural domain in the F-actin binding sites of gelsolin and $\alpha$-actinin. $J$ Cell Sci 14: 91-94.

Webb SE, Fowler RE, Oshaughnessy C, Pinder JC, Dluzewski AR, Gratzer WB, Bannister LH, Mitchell GH 1996. Contractile protein system in the asexual stages of the malaria parasite Plasmodium falciparum. Parasitology 112: 451-457.
Wesseling JG, Ree JM, Ponnudurai T, Smits MA, Schoenmakers JGG 1988a. Nucleotide sequence and deduced amino acid sequence of a Plasmodium falciparum actin gene. Mol Biochem Parasitol 27: 313-320.

Wesseling JG, Smits MA, Schoenmakers JGG 1988b. Extremely diverged actin proteins in Plasmodium falciparum. Mol Biochem Parasitol 30: 143-154.

Wesseling JG, Snijders PJF, Van Someren P, Jansen J, Smits MA, Schoenmakers JGG 1989. Stage-specific expression and genomic organization of the actin genes of the malaria parasite Plasmodium falciparum. Mol Biochem Parasitol 35: 167-176.

Wiser MF, Lanners HN 1992. Rapid transport of the acidic phosphoproteins of Plasmodium berghei and Plasmodium chabaudi from the intraerythrocytic parasite to the host membrane using a miniaturized fractionation procedure. Parasitol Res 78: 193-200.

Wolenski JS 1995. Regulation of calmodulin-binding myosins. Trends Cell Biol 5: 310-316. 